\title{
Comparative Analysis of Measurement after Recognition of Property, Plant and Equipment - IAS 16 vs. OMPF No. 1802/2014
}

\author{
PhD. Mărioara MOLOCINIUC (HRIṬCAN)
}

"Ştefan cel Mare" University of Suceava, Romania

\begin{abstract}
Valuating property, plant and equipment after recognition with the purpose of preparing the annual financial statements is an extremely important step in presenting a true and fair view of the entity. Thus, the companies must take into account the main valuation methods used and develop appropriate accounting policies and procedures to ensure that the users of financial and accounting information are properly informed and understand every change that occurs. The book value, respectively the carrying amount, of property, plant and equipment is represented abiding by the prudence concept, according to which every impairment or change from the determined value shall be taken into account. The efficiency with which these assets are valuated brings surplus value to the entity and has a direct impact on the financial statements.

The main objective of this article is to present the methods of valuation used to valuate property, plant and equipment. This way, at the end of the research the main applicable accounting treatments and the differences between IAS 16 Property, Plant and Equipment and Order of the Minister of Public Finance No. 1802/2014 for the approval of the Accounting regulations regarding the individual annual financial statements and consolidated annual financial statements, as subsequently amended and supplemented, will be understood.
\end{abstract}

Key terms: impairment, valuation, property, plant and equipment, revaluation, net carrying value, just value

JEL Classification: M41, M48

To cite this article: Mărioara Molociniuc (Hrițcan), Comparative Analysis of Measurement after Recognition of Property, Plant and Equipment - IAS 16 vs. OMPF No. 1802/2014, CECCAR Business Review, №3/2021, pp. 59-72, DOI: http://dx.doi. org/10.37945/cbr.2021.03.07

\section{Introduction}

Efforts have been made globally to improve financial and accounting communication, by ensuring transparency and creating a well-established business environment. Thus, in Romania, a large part of the entities applies the accounting regulations according to European directives, approved by the Order of the Minister of Public Finance No. 1802/2014. This order includes accounting rules and treatments that are largely similar to those in the International Financial Reporting Standards, but there are also some differences.

On this basis, we aim to discuss the main provisions of IAS 16 Property, Plant and Equipment and to highlight the differences between the two accounting regulations.

IAS 16 is of particular importance because the proportion of fixed assets in an entity's total assets is significant, which is why we need to apply the most appropriate treatment in order to be able to render the company's image as clearly as possible. Tangible assets must be highlighted to adequately reflect changes in market value. 
Mateș and Mustață (2004) claimed that in the near future we will see a mixed valuation model characterized both by the historical cost and the fair value. Entities use the historical cost as the basis for assessment due to tax reasons.

The measurement after recognition based on the input value of tangible assets in accordance with IAS 36 Impairment of Assets and IAS 16 Property, Plant and Equipment are performed in two ways: the first will lead to changes in the balance sheet assets, and the second, to changes in equity. In the first case, the measurement is made at the input value (historical cost) and any negative differences that may be observed will be recorded in the impairment adjustment account, ultimately affecting the accounting asset. In the second case, the measurement shall be made, at its choice, on the basis of fair value or discounted value, and the differences will influence the reserve account, in the sense of increasing or decreasing them, says Cioara (2010).

Brown and Finn (1980) highlight the importance of revaluation by defining it. Thus, they claim that the revaluation is a new formulation of the carrying amount of tangible fixed assets that does not have an impact on the entity's cash flow.

The approach taken by different specialists shows the importance of research regarding the methods for the subsequent valuation of fixed assets and the disclosure system in the financial statements.

The purpose of this work is to highlight the main aspects of IAS 16 so that at the end of the research the differences encountered between the standard and OMPF No. 1802/2014, as well as the applicable accounting treatment for the post-recognition measurement of tangible assets are identified. In this respect, this fundamental and applied research provides information on relevant definitions found in the analysis of tangible assets, as well as practical examples to understand the applicability of the standard as best possible and to highlight the observed gaps. The research findings can be a basis for future comparisons between the Romanian and the international legislation.

\section{? Research methodology}

This research represents a comparative analysis between the Romanian legislation on tangible assets, OMPF No. 1802/2014, and IAS 16 and also presents the impact of this information on the financial statements. The research methods used are qualitative analysis through documentation, observation and interpretation of the procedures used, as well as a comparative one using practical examples applicable to the two effective accounting regulations in Romania. As international and national regulations in this area are constantly changing, the comparison can highlight various relevant issues.

The main research objectives are the presentation of the implications of professional judgment in the valuation and revaluation of tangible assets, the impact of tangible assets on financial statements, and the conclusions reached thereon.

The main research questions are linked to the objectives of the research:

$\checkmark$ What are the main differences between Romanian and international legislation regarding the accounting of tangible assets?

\section{$\checkmark$ What is the impact of these differences on financial statements?}

\section{? The evaluation of tangible assets after recognition}

At the end of each financial year, all entities are required to perform the inventory process and complete the inventory register, but not before the final balances of all balance sheet accounts are established.

The valuation of asset items shall be carried out in accordance with the prudence concept that all write-downs arising shall be recognized, irrespective of whether the result of the financial year is profit or loss. Adjustments for depreciation of assets shall be made against expenses. The assets of the entity must not be overvalued or undervalued; they must represent the reality so that the financial statements reflect the true image of the firm. 
In evaluating the tangible assets, the accountant should pay attention to both internal sources of information such as physical or moral wear or changes in the use of the asset, the generation of profits, as well as to external sources of information represented by the market value of the asset, significant changes in the technological, economic or legal environment in which the entity operates.

The main steps of the assets' evaluation at the date of the inventory are:

- determining the inventory value of tangible assets on the basis of the prudence concept;

- the calculation of differences between inventory value and book value;

- determination of adjustments.

The entity shall choose one of the two models as accounting policy for the evaluation after recognition of the tangible assets:
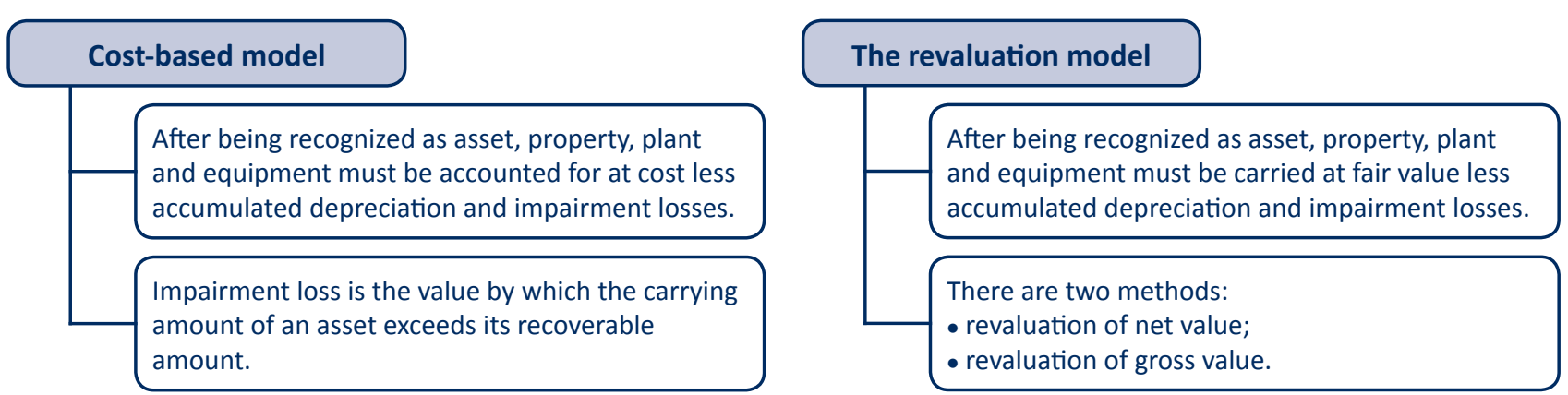

Source: Author's contribution.

\section{Cost-based method}

The inventory process for assets is performed by all entities, regardless of legislation, either national or international. Entities may choose a cost-based method as a method of evaluation, thus accounting for a value adjustment for any minus found between the book value and the inventory value. In this case, the asset is considered depreciated and the provisions of IAS 36 Impairment of Assets are applicable.

Value in use is the present value of the cash flows that an entity expects to obtain from the continued use of an asset and its disposal at the end of its useful life.

\section{If Book value $>$ Recoverable amount/Inventory value $\rightarrow$ Depreciation}

Recoverable amount $=\max$ [Fair value - Expenditure on the sale of assets; Value of use $]$

- Recording the depreciation:

6813

"Operating expenses on adjustments for impairment of fixed assets, investment property and bearer biological assets valued at cost"
$=$

\section{"Adjustments for depreciation or impairment losses} of fixed assets, investment property and bearer biological assets valued at cost"

- Write-off of depreciation (not before the depreciation test is performed):

$$
\text { 29X }
$$

"Adjustments for depreciation or impairment losses of fixed assets, investment property and bearer biological assets valued at cost"

\section{3}

"Income from adjustments for impairment of fixed assets, investment property and bearer biological assets valued at cost" 


\section{Example}

On 31.12.N-1, SC Mary SA acquires a building at the value of 720,000 lei, its useful life being 40 years. The method of depreciation is linear. In 10 years, when is expected that the building will be sold, the residual value is null. On 31.12. N+1, an impairment of the asset is found and the recoverable value of 560,000 lei is calculated, and on 31.12. $\mathrm{N}+3$ the recoverable value is 424,000 lei.

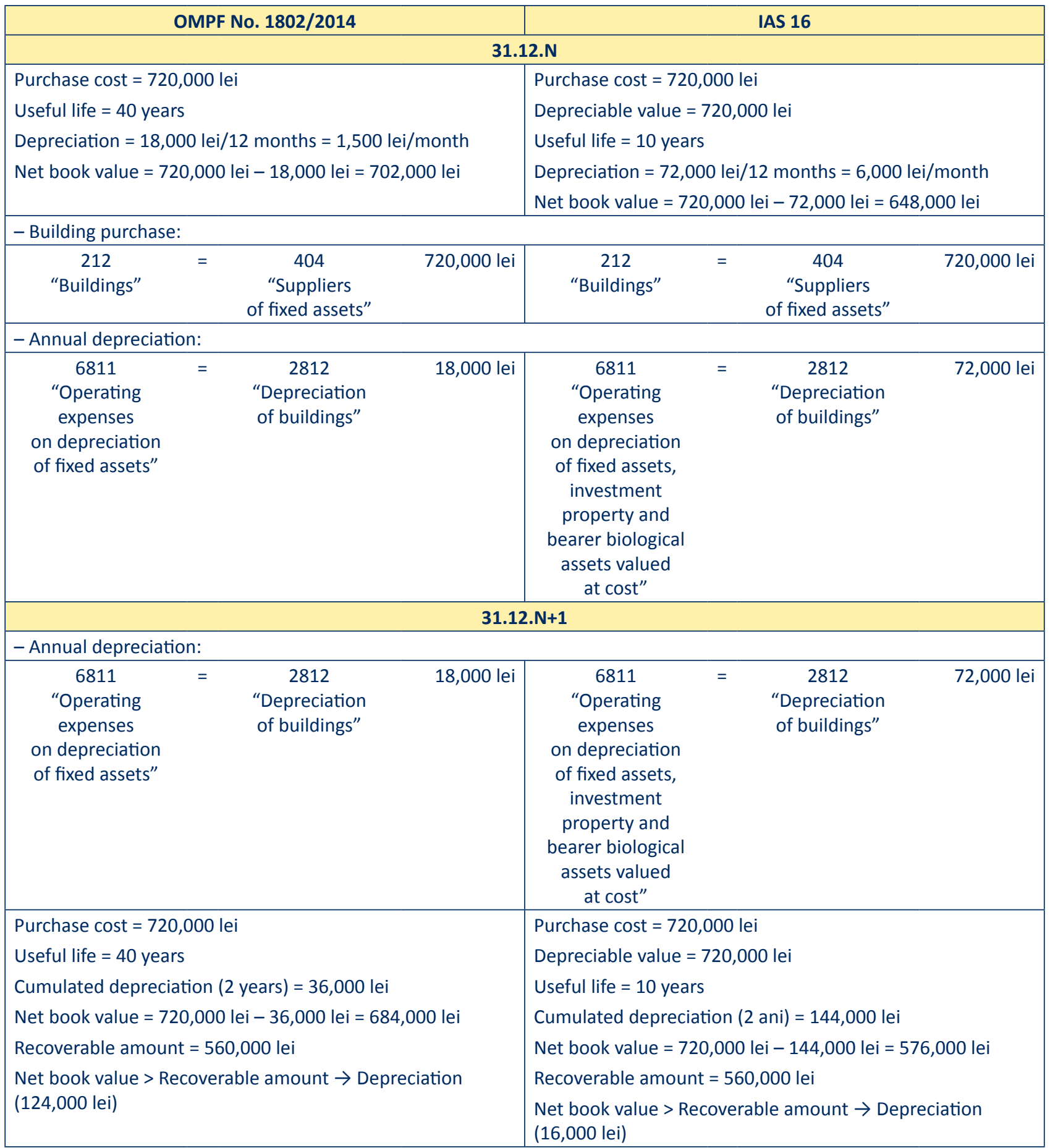




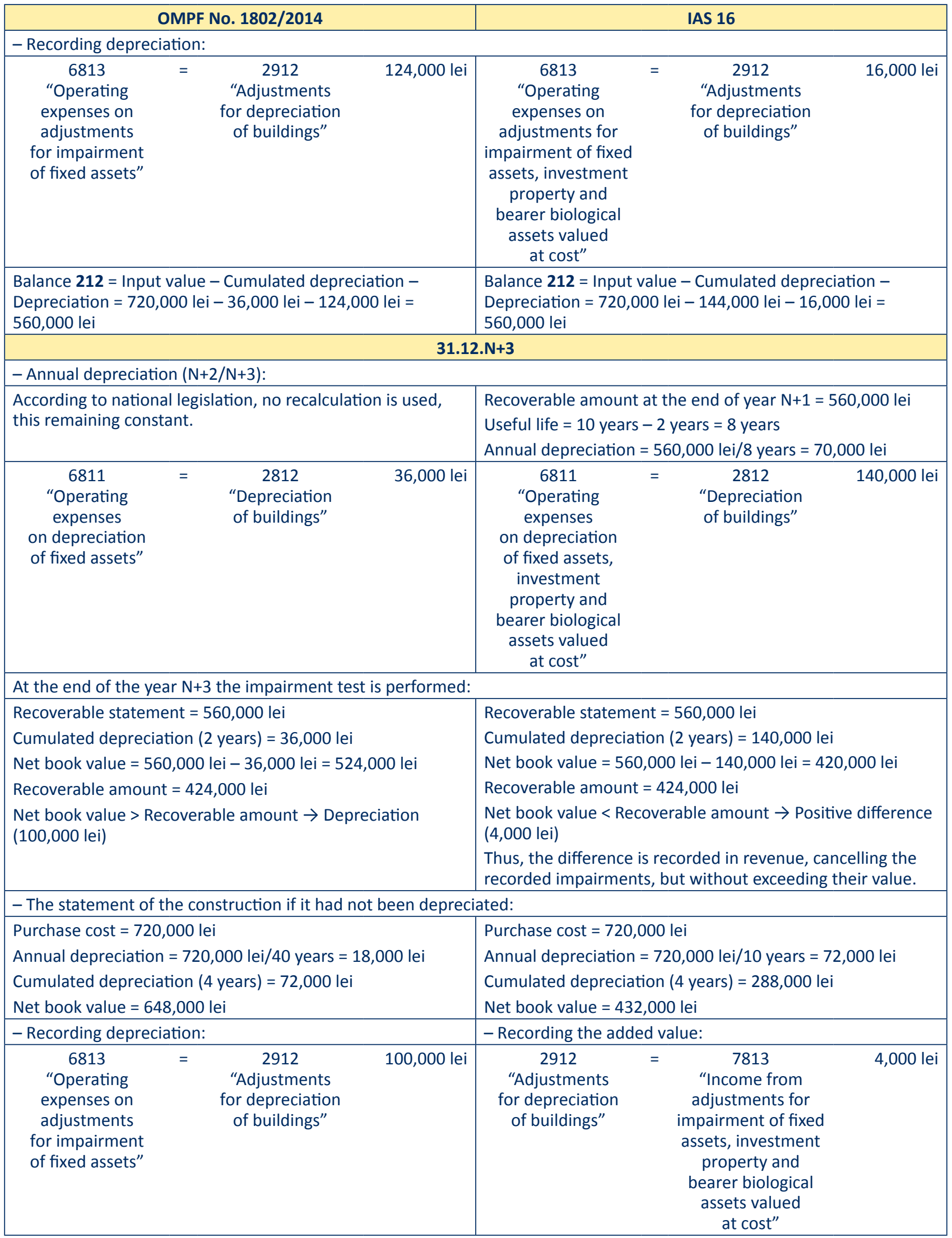




\begin{tabular}{|c|c|}
\hline OMPF No. $1802 / 2014$ & IAS 16 \\
\hline $\begin{array}{l}\text { The situation will be as follows: } \\
\text { Balance } \mathbf{2 9 1 2}=124,000 \text { lei }+100,000 \text { lei }=224,000 \text { lei } \\
\text { Balance } \mathbf{2 1 2}=\text { Input value }- \text { Cumulated depreciation }- \\
\text { Depreciation = 720,000 lei }-72,000 \text { lei ( } 4 \text { years) - } \\
224,000 \text { lei = 424,000 lei }\end{array}$ & $\begin{array}{l}\text { By resuming the loss of } 4,000 \text { lei on revenue, the situation } \\
\text { will be as follows: } \\
\text { Balance } 2912=16,000 \text { lei }-4,000 \text { lei }=12,000 \text { lei } \\
\text { Balance } 212=\text { Input value }- \text { Cumulated depreciation - } \\
\text { Depreciation = 720,000 lei }-144,000 \text { lei }(N / N+1)-140,000 \text { lei } \\
(N+2 / N+3)-12,000 \text { lei }=424,000 \text { lei }\end{array}$ \\
\hline
\end{tabular}

As noted, the differences are recorded directly in the profit and loss account, influencing the accounting result. Therefore, by making a comparative analysis between the two accounting regulations, we draw the following conclusions:

$\checkmark$ According to OMPF No. 1802/2014, the amount of 72,000 lei is highlighted in the construction depreciation expense account and the amount of 224,000 lei is highlighted in the account of adjustments for depreciation of assets.

$\checkmark$ According to IFRS, the depreciation expense of construction is 288,000 lei and the adjustments for depreciation of assets are 12,000 lei.

The differences are significant, with repercussions over the main economic and financial indicators and over the outcome. These differences shall be recorded in the account of deferred tax, which operates as a provision, and at the end, when the asset is no longer held by the entity, it shall be cancelled on the account of income.

\section{Revaluation method}

In the inventory process, entities can also opt for the revaluation method. Revaluation is a technique used in accounting to determine the market value of a fixed asset. Once chosen as an accounting policy, revaluation shall be performed with sufficient regularity so that the carrying amount of the asset does not differ significantly from the fair value at the balance sheet date.

\section{Revaluation method - essential elements}

\begin{tabular}{|c|c|c|}
\hline \multicolumn{2}{|c|}{ Net method } & Gross method/Revaluation index \\
\hline \multicolumn{2}{|c|}{$\begin{array}{l}\text { This method involves replacing the net book value by } \\
\text { the fair value. } \\
\text { Net book value = Historical cost - Cumulated depreciation } \\
\text { Depreciation will be removed from the gross carrying } \\
\text { amount of the asset and the net amount is recalculated } \\
\text { according to the level of fair value. } \\
\text { The difference between fair value and net book value of } \\
\text { the asset shall be shown as a plus or a minus value. }\end{array}$} & $\begin{array}{l}\text { In this method a revaluation index (discount) will be calculated, } \\
\text { which will be multiplied both by the gross value of the asset } \\
\text { and the accumulated depreciation of the asset. } \\
\text { Revaluation index = Fair value/Net book value } \\
\text { Depreciation shall be recalculated proportionally with the } \\
\text { change in the gross carrying amount of the asset, so that the } \\
\text { carrying amount of the asset after revaluation is equal to its } \\
\text { fair value. } \\
\text { When the revaluation (discount) index is overwritten, an } \\
\text { increase in the value of the asset occurs, and when the index } \\
\text { is sub-unit, the asset is depreciated. }\end{array}$ \\
\hline \multicolumn{3}{|c|}{$\begin{array}{l}\text { The revaluation of tangible assets is the replacement of book value by fair value. The revaluation is performed by the } \\
\text { approved evaluators and should be carried out regularly enough. The frequency of revaluation is based on changes in fair } \\
\text { value. The policy chosen (cost or revaluation) applies to an entire class of fixed assets. }\end{array}$} \\
\hline \multicolumn{3}{|c|}{ The accounting treatment of the revaluation outcome } \\
\hline $\begin{array}{l}\text { Book value }<\text { Fair value } \rightarrow \\
\text { Added value }\end{array}$ & \multicolumn{2}{|c|}{$\begin{array}{l}\text { The carrying amount of the asset is increased as a result of the revaluation: } \\
\checkmark \text { The increase is recognized in the revaluation reserve (account } 105 \text { "Revaluation } \\
\text { reserves"). } \\
\checkmark \text { The increase is recognized in the profit and loss account if it compensates for an } \\
\text { impairment recorded at a previous revaluation (account } 755 \text { "Income from revaluation } \\
\text { of tangible assets"). }\end{array}$} \\
\hline
\end{tabular}




\begin{tabular}{|l|l|l|}
\hline \multicolumn{2}{|c|}{$\begin{array}{l}\text { The accounting treatment of the revaluation outcome } \\
\text { Less value }\end{array}$} & $\begin{array}{l}\text { The carrying amount of the asset decreases as a result of the revaluation: } \\
\checkmark \text { The revaluation reserve is reduced (account 105) within the limit of the creditor balance. } \\
\checkmark \text { Is shown in the profit and loss account (account } 655 \text { "Expenses for the revaluation of } \\
\text { tangible assets") if there is no revaluation reserve or if the depreciation found exceeds } \\
\text { the existing revaluation reserve. }\end{array}$ \\
\multicolumn{1}{|c|}{$\begin{array}{c}1175 \\
\text { "Revaluation } \\
\text { reserves" }\end{array}$} & $\begin{array}{l}\checkmark \text { When the tangible asset is derecognized: sale, disposal, } \\
\text { "Deferred result } \\
\text { representing the } \\
\text { surplus made from } \\
\text { the revaluation } \\
\text { of assets" }\end{array}$ & $\begin{array}{l}\checkmark \text { As tangible fixed asset is used: difference between fair value } \\
\text { depreciation and book value depreciation. }\end{array}$ \\
\hline
\end{tabular}

Source: Author's contribution.

When an item of property, plant and equipment is revalued, the whole class to which that item belongs shall be revalued. Items in a class of property, plant and equipment shall be revalued simultaneously to avoid selective revaluation and reporting in the financial statements of amounts which are a combination of costs and values calculated at different dates. Therefore, according to IAS 16, a particular asset class may be revalued on an ongoing basis, if such revaluation can be carried out in a short time and if these revaluations can always be updated.

In order to understand the underlying mechanism in the revaluation accounting as effectively as possible, we'll present some examples.

\section{Example 1}

SC Mary SA has a machine with the value of 100,000 lei, the useful life is 10 years, the cumulated depreciation at the date of the revaluation is 20,000 lei. The fair value at the revaluation date is 150,000 lei.

\begin{tabular}{|c|c|c|c|c|c|c|}
\hline \multicolumn{4}{|c|}{ Net method } & \multicolumn{3}{|c|}{ Gross method/Revaluation index } \\
\hline \multicolumn{4}{|c|}{ Input value $=100,000$ lei } & \multicolumn{3}{|l|}{ A revaluation index } \\
\hline \multicolumn{4}{|c|}{ Cumulated depreciation $=20,000$ lei } & \multicolumn{3}{|c|}{$I=$ Fair value $/$ Net book value $=150,000$ lei $/ 80,000$ lei $=1.875$} \\
\hline \multicolumn{4}{|c|}{ Net book value $=80,000$ lei } & \multicolumn{3}{|c|}{ Gross revalued amount $=100,000$ lei $\times 1.875=187,500$ lei } \\
\hline \multicolumn{4}{|c|}{ Fair value $=150,000$ lei } & \multicolumn{3}{|c|}{ Revalued cumulated depreciation = 20,000 lei $\times 1.875=$} \\
\hline \multicolumn{4}{|c|}{ Added value $=70,000$ lei } & \multirow{3}{*}{\multicolumn{3}{|c|}{$\begin{array}{l}\text { Net revalued amount (Fair value) }=\text { Gross revalued amount }- \\
\text { Revalued cumulated depreciation }=187,500 \text { lei }-37,500 \text { lei }= \\
150,000 \text { lei }\end{array}$}} \\
\hline \multicolumn{4}{|c|}{ - Cancelling the depreciation: } & & & \\
\hline \multirow{2}{*}{$\begin{array}{c}2813 \\
\text { "Depreciation } \\
\text { of machinery" }\end{array}$} & \multirow{2}{*}{\multicolumn{2}{|c|}{$\begin{array}{c}2131 \\
\text { "Technological } \\
\text { equipment" }\end{array}$}} & \multirow[t]{2}{*}{20,000 lei } & & & \\
\hline & & & & \multirow{3}{*}{$\begin{array}{l}2131 \\
\text { "Technological } \\
\text { equipment" }\end{array}$} & \multirow{3}{*}{$\begin{array}{c}\% \\
2813 \\
\text { "Depreciation } \\
\text { of machinery" } \\
105 \\
\text { "Revaluation } \\
\text { reserves" }\end{array}$} & \multirow{2}{*}{$\frac{87,500 \text { lei }}{17,500 \text { lei }}$} \\
\hline \multicolumn{4}{|c|}{ - Recording the added value: } & & & \\
\hline $\begin{array}{c}2131 \\
\text { "Technological } \\
\text { equipment" }\end{array}$ & $=$ & $\begin{array}{l}105 \\
\text { "Revaluation } \\
\text { reserves" }\end{array}$ & 70,000 lei & & & 70,000 lei \\
\hline \multicolumn{4}{|c|}{$\begin{array}{l}\text { Balance } \mathbf{2 1 3 1}=\text { Input value }- \text { Cumulated depreciation }+ \\
\text { Added value }=100,000 \text { lei }-20,000 \text { lei }+70,000 \text { lei }=150,000 \text { lei }\end{array}$} & \multicolumn{3}{|c|}{$\begin{array}{l}\text { Balance } \mathbf{2 1 3 1}=\text { Input value }- \text { Cumulated depreciation }+ \\
\text { Added value }=100,000 \text { lei }-37,500 \text { lei }+87,500 \text { lei }=150,000 \text { lei }\end{array}$} \\
\hline
\end{tabular}

Regardless of the method we use, both the amount at which the asset is shown in the financial statements and the amount of the revaluation reserve are similar. 


\section{Example 2}

On 31.12.N-1, SC Mary SA purchases a building at the cost of 800,000 lei. The useful life of the building is estimated at 40 years and the entity expects to sell it in 10 years. The current sale price of a similar building 10 years old is 250,000 lei. The amortization method used by the entity is linear and the residual value does not change over the useful life. Therefore:

At 31.12. $N+1$ the building is revalued at fair value of 750,000 lei and the depreciation is considered to be removed from the gross book value of the asset and the revaluation surplus will be transferred to the retained earnings. At 31.12. $\mathrm{N}+2$ the fair value of the building is 760,000 lei. At 31.12. $\mathrm{N}+3$ the entity's management decides to switch from the fair value revaluation model to the cost-based model.

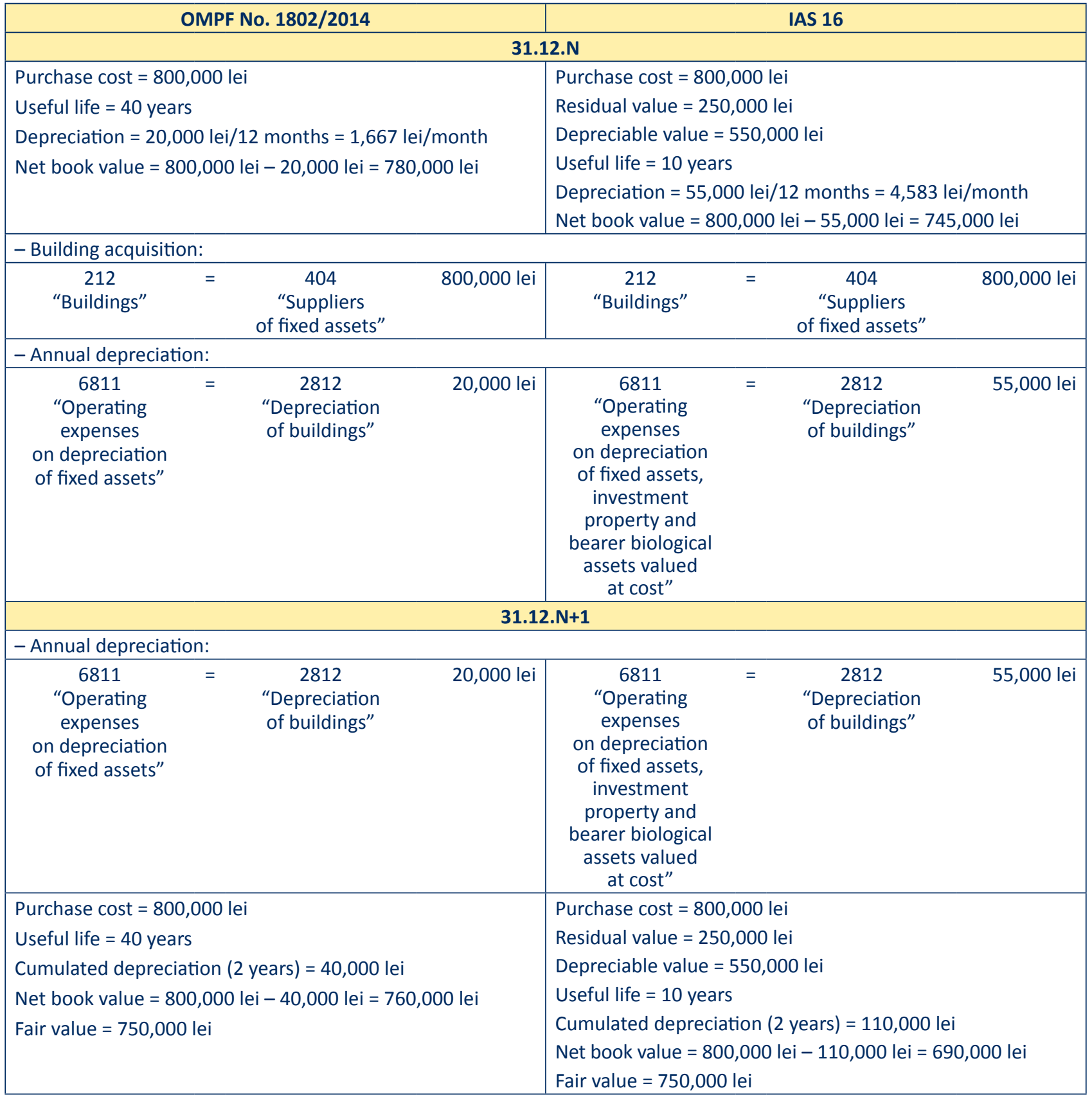




\begin{tabular}{|c|c|c|c|c|c|c|c|}
\hline \multicolumn{4}{|c|}{ OMPF No. $1802 / 2014$} & \multicolumn{4}{|c|}{ IAS 16} \\
\hline \multicolumn{4}{|c|}{ Net book value $>$ Fair value $\rightarrow$ Negative difference $(10,000$ lei) } & \multicolumn{4}{|c|}{ Net book value $<$ Fair value $\rightarrow$ Positive difference $(60,000$ lei } \\
\hline \multicolumn{8}{|c|}{ - Cancelling the depreciation: } \\
\hline $\begin{array}{c}2812 \\
\text { "Depreciation } \\
\text { of buildings" }\end{array}$ & $=$ & $\begin{array}{c}212 \\
\text { "Buildings" }\end{array}$ & 40,000 lei & $\begin{array}{c}2812 \\
\text { "Depreciation } \\
\text { of buildings" }\end{array}$ & $=$ & $\begin{array}{c}212 \\
\text { "Buildings" }\end{array}$ & 110,000 lei \\
\hline \multicolumn{4}{|c|}{ - Recording the negative difference: } & \multicolumn{4}{|c|}{ - Recording the added value on account of the reserve: } \\
\hline $\begin{array}{c}655 \\
\text { „Expenses for } \\
\text { the revaluation } \\
\text { of tangible assets” }\end{array}$ & $=$ & $\begin{array}{c}212 \\
\text { "Buildings" }\end{array}$ & 10,000 lei & $\begin{array}{c}212 \\
\text { "Buildings" }\end{array}$ & $=$ & $\begin{array}{c}105 \\
\text { "Revaluation } \\
\text { reserves" }\end{array}$ & 60,000 lei \\
\hline $\begin{array}{l}\text { Balance } \mathbf{2 1 2}=800, \\
750,000 \text { lei }\end{array}$ & $0 \mathrm{le}$ & 40,000 lei $-10,00$ & & $\begin{array}{l}\text { Balance } \mathbf{2 1 2}=800 \\
750,000 \text { lei }\end{array}$ & & $-110,000$ lei +60 & \\
\hline \multicolumn{8}{|c|}{ 31.12.N+2 } \\
\hline \multicolumn{8}{|c|}{ - Annual depreciation: } \\
\hline $\begin{array}{c}6811 \\
\text { "Operating } \\
\text { expenses } \\
\text { on depreciation } \\
\text { of fixed assets" }\end{array}$ & $=$ & $\begin{array}{c}2812 \\
\text { "Depreciation } \\
\text { of buildings" }\end{array}$ & 19,737 lei & $\begin{array}{c}6811 \\
\text { "Operating } \\
\text { expenses } \\
\text { on depreciation } \\
\text { of fixed assets, } \\
\text { investment } \\
\text { property and } \\
\text { bearer biologica } \\
\text { assets valued } \\
\text { at cost" }\end{array}$ & $=$ & $\begin{array}{c}2812 \\
\text { "Depreciation } \\
\text { of buildings" }\end{array}$ & 62,500 lei \\
\hline $\begin{array}{l}\text { Book value }=750,0 \\
\text { Useful life }=40 \text { year } \\
\text { Annual depreciatio } \\
\text { Net book value }=75 \\
\text { Fair value }=760,00 \\
\text { Net book value }<\text { Fa }\end{array}$ & $\begin{array}{l}\text { lei } \\
-2 \\
=75 \\
00 \\
\text { lei } \\
\text { val }\end{array}$ & $\begin{array}{l}\text { rs }=38 \text { years } \\
00 \text { lei } / 38 \text { years }= \\
-19,737 \text { lei }=73 \\
\rightarrow \text { Positive differe }\end{array}$ & $\begin{array}{l}37 \text { lei } \\
3 \text { lei } \\
(29,737 \text { lei) }\end{array}$ & $\begin{array}{l}\text { Book value }=750, \\
\text { Residual value }=2 \\
\text { Depreciable value } \\
\text { Useful life = } 10 \text { ye } \\
\text { Annual depreciati } \\
\text { Net book value = } \\
\text { Fair value = 760,0 } \\
\text { Net book value }\end{array}$ & $\begin{array}{l}-2 \\
=5 \\
, 00 \\
\text { ei } \\
\text { val }\end{array}$ & $\begin{array}{l}\text { ei } \\
\text { oo lei }-250,000 \text { le } \\
\text { ears }=8 \text { years } \\
000 \text { lei } 8 \text { years }= \\
\text { lei }-62,500 \text { lei }=6 \\
\text { e } \rightarrow \text { Positive differ }\end{array}$ & $\begin{array}{l}00,000 \text { lei } \\
00 \text { lei } \\
00 \text { lei } \\
(72,500 \text { lei) }\end{array}$ \\
\hline \multicolumn{8}{|c|}{ - Cancelling the depreciation: } \\
\hline $\begin{array}{c}2812 \\
\text { "Depreciation } \\
\text { of buildings" }\end{array}$ & $=$ & $\begin{array}{c}212 \\
\text { "Buildings" }\end{array}$ & 19,737 lei & $\begin{array}{c}2812 \\
\text { "Depreciation } \\
\text { of buildings" }\end{array}$ & $=$ & $\begin{array}{c}212 \\
\text { "Buildings" }\end{array}$ & 62,500 lei \\
\hline \multicolumn{4}{|c|}{ - Cancelling the depreciation: } & \multicolumn{4}{|c|}{ - Registration plus on account of the reserve: } \\
\hline $\begin{array}{c}212 \\
\text { "Buildings" }\end{array}$ & $=$ & $\begin{array}{c}\% \\
755 \\
\text { "Income from } \\
\text { revaluation } \\
\text { tangible assets" } \\
105 \\
\text { "Revaluation } \\
\text { reserves" }\end{array}$ & $\frac{29,737 \text { lei }}{10,000 \text { lei }}$ & $\begin{array}{c}212 \\
\text { "Buildings" }\end{array}$ & $=$ & $\begin{array}{c}105 \\
\text { "Revaluation } \\
\text { reserves" }\end{array}$ & 72,500 lei \\
\hline \multicolumn{4}{|c|}{$\begin{array}{l}\text { - Recording the negative difference between depreciation } \\
\text { at input value and depreciation at fair value }(20,000 \text { lei - } \\
19,737 \text { lei): }\end{array}$} & \multicolumn{4}{|c|}{$\begin{array}{l}\text { - Registering the reserve in the reported result as the asset } \\
\text { is used (Fair value depreciation - Book value depreciation: } \\
62,500 \text { lei }-55,000 \text { lei): }\end{array}$} \\
\hline $\begin{array}{c}212 \\
\text { "Buildings" }\end{array}$ & $=$ & $\begin{array}{l}105 \\
\text { "Revaluation } \\
\text { reserves" }\end{array}$ & (263 lei) & $\begin{array}{l}105 \\
\text { "Revaluation } \\
\text { reserves" }\end{array}$ & $=$ & $\begin{array}{l}1175 \\
\text { "Deferred result } \\
\text { representing the } \\
\text { surplus made fron } \\
\text { the revaluation } \\
\text { of assets" }\end{array}$ & 7,500 lei \\
\hline
\end{tabular}




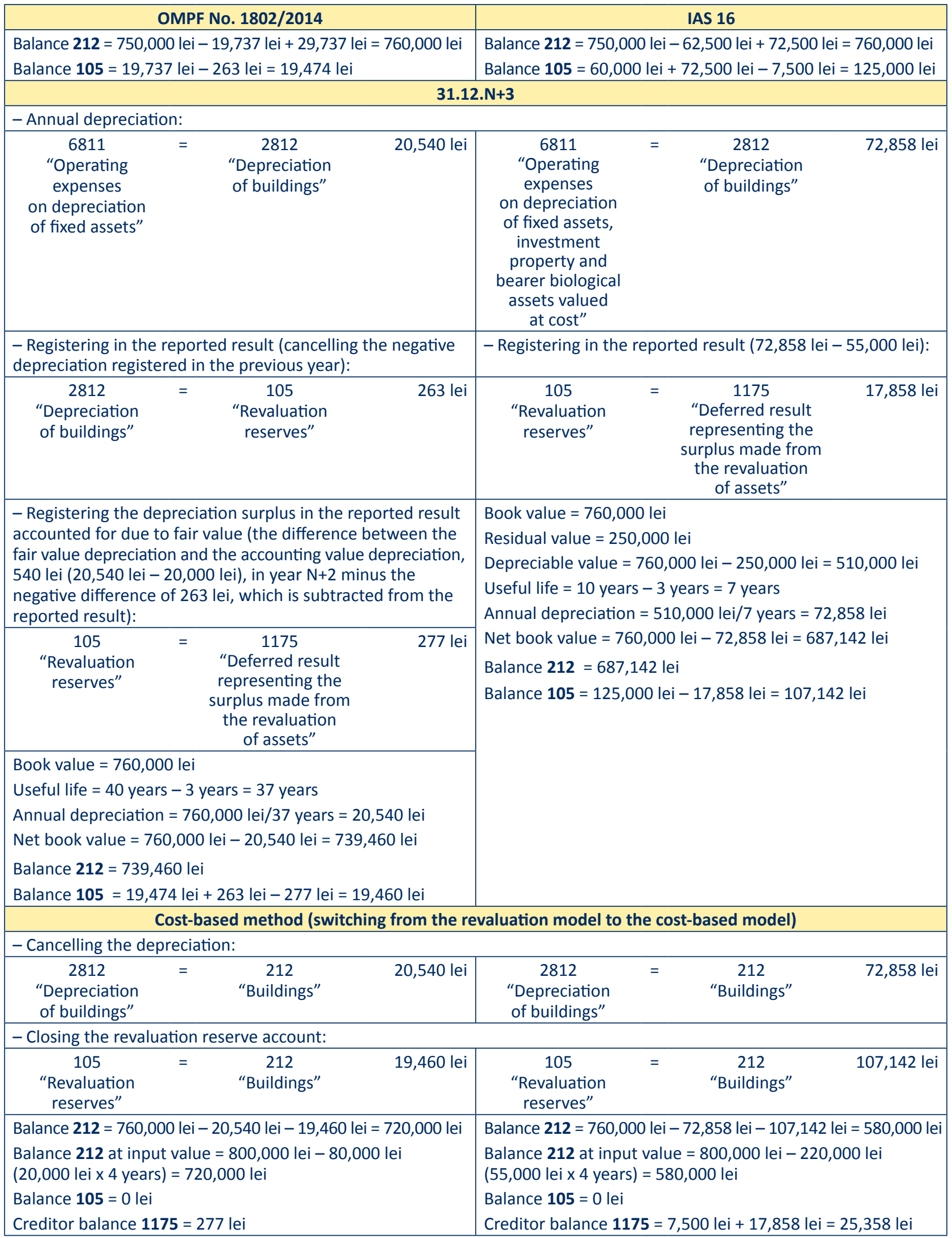


If entities want to change from one valuation method to another, they must take certain aspects into account. Firstly, any change in accounting policies must be approved and reasoned by the management of the unit by means of a signed and stamped report, secondly, particular attention shall be paid to the time from which the change occurs, if the method of revaluation is changed from the cost-based method to the previous accounting policy must be applied until the time of the change. For the comparability of financial statements, it is recommended that the changes in accounting policies take place from the following year.

In our case, the depreciation, the reserve and the reported result are taken into account at the end of year $\mathrm{N}+3$, and from January $\mathrm{N}+4$ the cost-based method will apply. The revaluation reserve shall be cancelled on 31.12. $\mathrm{N}+3$ on behalf of the asset. Companies applying the cost-based valuation model have no reason to have a balance in the account of 105 .

In the example presented, the entity applied as an accounting policy the transfer of the revaluation reserve to the income account carried forward as the asset is depreciated, which implies that, with the change of method, the amount in account 1175 will be taxed, is considered an income-equivalent element and is added up in the calculation of corporation tax.

As we can see, the differences between the two accounting regulations clearly influence the financial statements as a whole. In the situation of the global result, according to IFRS an expense with much higher depreciation is present than in the Romanian accounting, with impact on deferred corporation tax. The revaluation reserve is worth 107,142 lei in accordance with IAS 16 at the end of year $N+3$, and 19,460 lei according to OMPF No. 1802/2014. The credit balance of account 1175 is the surplus between depreciation calculated at book value and depreciation at fair value, which means that the company has also recorded depreciation expenses due to the fact that it used the revaluation method in the amount of 277 lei according to OMPF No. 1802/2014 and 25,358 lei according to IFRS.

\section{- Successive revaluations}

In order to best exemplify the mechanism of accounting for the revaluation, a parcel of land will be taken as an example because the land has an unlimited useful life and is not depreciated. There are exceptions when land is depreciable, namely in situations where it is used as a landfill site or as exploitation quarries, but the example chosen is a common one.

\section{Example}

At 01.01.N, SC Mary SA purchased a land at the cost of 240,000 lei. At 31.12.N the land was revalued by an evaluator at the value of 324,000 lei. At $31.12 . N+1$ the fair value of the land is 208,000 lei, at $31.12 . N+2-$ 304,000 lei, at 31.12.N+3-252,000 lei, and at 31.12. N+4 - 272,000 lei.

The situation under OMPF No. 1802/2014 and IFRS is as follows:

\begin{tabular}{|c|c|c|}
\hline \multicolumn{3}{|c|}{ 31.12.N } \\
\hline Book value $<$ Fair value $\rightarrow$ Added value & $\begin{array}{l}\text { Cost }(\text { Book value })=240,000 \text { lei } \\
\text { Fair value }=324,000 \text { lei } \\
\text { Surplus from revaluation }=84,000 \text { lei }\end{array}$ & \\
\hline \multicolumn{3}{|c|}{$\begin{array}{l}\text { We see a positive difference that will be recorded on account of the revaluation reserve because it is the first revaluation } \\
\text { and there are no negative differences from the previous period that we have to take into account. }\end{array}$} \\
\hline $\begin{array}{l}2111 \\
\text { "Land" }\end{array}$ & $\begin{array}{c}105 \\
\text { "Revaluation reserves" }\end{array}$ & 84,000 le \\
\hline \multicolumn{3}{|c|}{ 31.12. $\mathrm{N}+1$} \\
\hline Book value $>$ Fair value $\rightarrow$ Less value & $\begin{array}{l}\text { Book value }=324,000 \text { lei } \\
\text { Fair value }=208,000 \text { lei } \\
\text { Minus from revaluation }=116,000 \text { lei }\end{array}$ & \\
\hline
\end{tabular}




\subsection{2. $\mathrm{N}+1$}

The negative difference in value is 116,000 lei and the available reserve existing in the accounts is 84,000 lei. Thus, the existing revaluation reserve will be cancelled and the difference of 32,000 lei $(116,000$ lei $-84,000$ lei) is left uncovered and will be recorded in expenses.

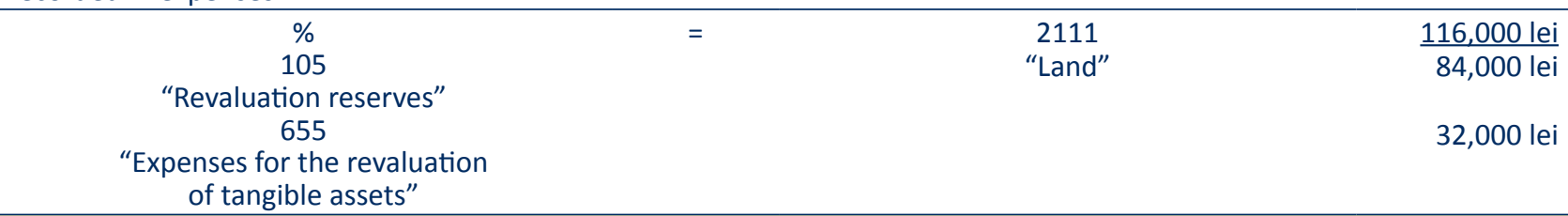

31.12. $\mathrm{N}+2$

Book value $<$ Fair value $\rightarrow$ Added value

Book value $=208,000$ lei

Fair value $=304,000$ lei

Surplus from revaluation $=96,000$ lei

In this situation, the previous revaluation is taken into account, in which a depreciation of 32,000 lei is recorded. Thus, the positive difference in the current revaluation of 96,000 lei will be taken to an income portion $(32,000$ lei) to compensate for the previous year's expenditure and the rest will be switched to the revaluation reserve $(64,000$ lei).

\begin{tabular}{|c|c|c|c|}
\hline $\begin{array}{c}2111 \\
\text { "Land" }\end{array}$ & $=$ & $\begin{array}{c}\% \\
105 \\
\text { "Revaluation reserves" } \\
755 \\
\text { "Income from revaluation } \\
\text { of tangible assets" }\end{array}$ & $\begin{array}{l}\frac{96,000 \text { lei }}{64,000 \text { lei }} \\
32,000 \text { lei }\end{array}$ \\
\hline \multicolumn{4}{|c|}{ 31.12. $\mathrm{N}+3$} \\
\hline Book value $>$ Fair value $\rightarrow$ Less value & & $\begin{array}{l}\text { Book value }=304,000 \text { lei } \\
\text { Fair value }=252,000 \text { lei } \\
\text { Minus from revaluation }=52,000 \text { lei }\end{array}$ & \\
\hline
\end{tabular}

In this situation, as in the case of the revaluation in year $\mathrm{N}+1$, there is an impairment, only that this time the depreciation will be treated differently because there is a revaluation reserve available. This negative difference in value will diminish the revaluation reserve. Balance 105 is 12,000 lei $(64,000$ lei $-52,000$ lei).

\begin{tabular}{|c|c|c|c|}
\hline $\begin{array}{c}105 \\
\text { "Revaluation reserves" }\end{array}$ & $=$ & $\begin{array}{l}2111 \\
\text { "Land" }\end{array}$ & 52,000 lei \\
\hline \multicolumn{4}{|c|}{ 31.12. $\mathrm{N}+4$} \\
\hline Book value $<$ Fair value $\rightarrow$ Added value & & $\begin{array}{l}\text { Book value }=252,000 \text { lei } \\
\text { Fair value }=272,000 \text { lei } \\
\text { Surplus from revaluation }=20,000 \text { lei }\end{array}$ & \\
\hline
\end{tabular}

The revaluation surplus will be recorded in revaluation reserves because there are no negative differences from the previous revaluation. The balance of 105 was 12,000 lei and will increase by 20,000 lei, thus, the final balance will be 32,000 lei.

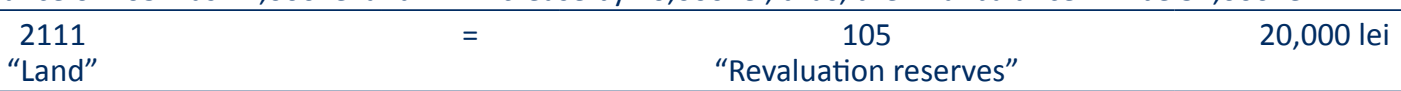

As we can see, the importance of the information presented in the explanatory notes on the history of a revalued asset is critical. The accountant may be changed for various reasons, but the information remaining is useful for the person who replaces him as he must understand each previously recognised value difference. Any accounting professional, when performing accounting or auditing services, shall identify the reference framework and then carefully read the accounting policies in order to better understand the nature of the operations as well as the chosen accounting methods.

\section{Dxplanatory notes on property, plant and equipment}

The definition of the accounting policy in IAS 8 Accounting Policies, Changes in Accounting Estimates and Errors, as well as in Romanian regulation is as follows: it represents specific principles, bases, conventions, rules and practices applied by an entity in preparing and presenting financial statements. 
Entities are free to choose the appropriate accounting policy that they must apply consistently. Specific accounting policies shall be adopted by an entity according to its characteristics and the presentation of the annual financial statements. Policy change can come from a competent authority or at the initiative of management when it believes that a change in accounting policy would lead to clearer and more credible and effective results. The effects of the change in accounting policy are operated on account of expense accounts and revenue accounts, taking into account the tax implications and, if these are impossible to determine, the change will be implemented in the following year.

Each set of financial statements must contain sufficient information to be understood by the relevant stakeholders. The accounting policy adopted must also be presented in such a way that the differences in value are certified accordingly.

For each class of tangible assets, the information presented is as follows:

- the evaluation basis used to determine the input value;

- the depreciation method used;

- the useful life;

- the gross book value and cumulated depreciation at the beginning and end of the period;

- inflows of fixed assets, the assets held for disposal, acquisitions resulted from business combinations, any increase or decrease resulted from revaluations and losses from recognized depreciations or registered directly in other elements of comprehensive income according to IAS 36, as well as any change that intervenes;

- the pledged or mortgaged assets;

- the amount of expenditure recognised in the book value of tangible assets during construction;

- the amount of compensation received or receivable from third parties for impairment, lost or abandoned tangible assets that are included in profit or loss.

In regard to revalued tangible assets, their situation is as follows:

- date of their revaluation;

- data regarding the independent evaluator who performed the assessment and the procedures carried out by him;

- the methods applied for the estimation of the fair value of tangible assets;

- for each tangible asset, the book value which would have been recognised if the asset had been recorded in accordance with the cost-based model;

- the revaluation surplus, indicating the change related to the period and any restrictions related to the distribution of the balance to shareholders.

IAS 16 states the obligation of explanatory notes and accounting policies. According to IFRS, the complete set of financial statements includes the statement of financial position, the statement of comprehensive income, the statement of changes in equity, the statement of cash flows, notes and accounting policies.

In Romanian law, this set applies only to the large entities, referred to in para. 9(4) from OMPF No. 1802/2014, and to medium entities that exceed two of the three classification criteria (total assets, net turnover and average number of employees) in two consecutive financial years.

\section{$\partial$ Conclusions}

The aim to reach a common language so that users of financial and accounting information are able to communicate as easily as possible is increasingly substantial. Romania tends to adhere more and more to the European and international standards so the gaps encountered are getting smaller.

The research presented proves the importance of tangible assets and valuation methods used in the exercise of the accounting profession. With the help of practical examples, the research aimed to highlight the gaps between the two accounting regulations, namely standard IAS 16 and OMPF No. 1802/2014. The identification of the reference framework is important both for the accounting professional, be it an auditor, accounting expert or evaluator, and for users of the accounting information. Investors are directly interested in both transparency of accounting and the advantages and disadvantages of applicable national law. 
The impact of these methods on the financial statements are substantial, for this reason each economic entity is obliged to provide in the explanatory notes details of the applicable reporting framework, the accounting regulations which were taken into account when the financial statements were prepared and the accounting policies used. Any change in the accounting policies shall be mentioned in the explanatory notes together with the nature, the reasons for the decision taken and their effects on the reporting made.

In Romania, accounting policies related to tangible assets are adopted according to the companies' needs. The revaluation of tangible assets is also frequently done for buildings only because the building tax applies in much higher rates if a revaluation is not performed in the last three years.

In a research carried out on field situations we found that the entities apply the cost-based method because it is much more practical and the revaluation is performed only for the building, possibly land, but only for tax purposes, for local taxes, not registering them in the accounts.

\section{References}

1. Bâtcă-Dumitru, C.-G., Sahlian, D.-N., Irimescu, A.-M. (2018), Contabilitate şi raportare financiară, ediția a II-a, Editura CECCAR, Bucureşti.

2. Brown, P., Finn, F. (1980), Asset Revaluations and Share Prices: Alternative Interpretations of a Study by Sharpe and Walker, in R. Ball, P. Brown, F. Finn, R. Officer (Editors), Share Markets and Portfolio Theory, University of Queensland Press.

3. Cioara, N.M. (2010), Studiu comparativ privind politica de reevaluare a imobilizărilor corporale în România şi Marea Britanie, The Romanian Economic Journal, Vol. 13, No. 35, pp. 101-147.

4. Ciocan, C.C. (2019), Prudence vs. Credibility. A Formal Comparative Analysis Between Romanian Accounting Regulations and IFRS, Audit Financiar, Vol. XVII, No. 1(153), pp. 114-123.

5. Mateș, D., Pop, A. (2007), Financial Accounting, Editura Alma Mater, Cluj-Napoca.

6. Matiș, D., Mustață, R.V. (2004), De la cost istoric la valoare justă (From Historical Cost to Fair Value), in Audit și convergență contabilă, Editura Sincron, Cluj-Napoca.

7. Mihăilă, S., Busuioc, M. (2019), Accounting Treatment of Fixed Assets from the Perspective of IAS 16 and NAS, in Simpozion Ştiințific Internațional al Tinerilor Cercetători, Ediția a XVII-a, Chişinău, Moldova, pp. 108-110.

8. Law No. $227 / 2015$ on the Fiscal Code, Official Gazette No. $688 / 10.09 .2015$, as subsequently amended and supplemented.

9. Order of the Minister of Public Finance No. 1802/2014 for the approval of the Accounting regulations regarding the individual annual financial statements and consolidated annual financial statements, Official Gazette No. 963/30.12.2014, as subsequently amended and supplemented.

10. Order of the Minister of Public Finance No. 2844/2016 for the approval of the Accounting regulations compliant with the International Financial Reporting Standards, Official Gazette No. 1020 și 1020 bis/ 19.12.2016, as subsequently amended and supplemented.

11. Order of the Minister of Public Finance No. 666/2015 on the application of the Accounting regulations compliant with the International Financial Reporting Standards by some entities with state capital, Official Gazette No. 442/22.06.2015.

12. www.aspaas.gov.ro

13. www.cafr.ro

14. www.ceccar.ro

15. www.ifrs.org

$\stackrel{M}{4}$ Acknowledgment: This paper received financial support through the project entitled "DECIDE - Development Through Entrepreneurial Education and Innovative Doctoral and Postdoctoral Research", code POCU/380/6/13/125031, project co-financed from the European Social Fund through the Operational Program Human Capital 2014-2020. 